\title{
PENYULUHAN RENCANA PEMBANGUNAN DESA \\ DI DESA KURANJI DALANG KECAMATAN LABUAPI KABUPATEN LOMBOK BARAT PROVINSI NUSA TENGGARA BARAT
}

\author{
Wahidin $^{1}$, M. Irwan'2, M. Firmansyah ${ }^{3}$, Endang Astuti ${ }^{4}$ \\ Fakultas Ekonomi dan Bisnis - Universitas Mataram
}

wahidin.april11@gmail.com

\begin{abstract}
ABSTRAK
Desa umumnya memiliki kekayaan alam melimpah sehingga dapat menjadi modal untuk pengembangan ekonomi dan pariwisata. Desa Kuranji Dalang adalah salah satu desa yang memiliki keunggulan tersebut. Potensi yang dimiliki antara lain pantai, penangkaran penyu dan pegunungan yang menawan. Disamping itu ada produk lokal yang diproduksi masyarakat Kuranji Dalang namun masih bermasalah dalam pemasaran. Diperlukan perencanaan yang baik untuk mengelola potensi wisata. Beberapa tahapan penyuluhan tersebut terdiri dari, 1) Perencanaan pembangunan jangka menengah (RPJM) desa dari aspek teoritis dan 2) perencanaan pengembangan bisnis yaitu aspek produksi (barang dan jasa), aspek distribusi, komersialisasi dan pengembangan pasar.

Kata Kunci: Pengembangan Ekonomi, Pariwisata, Perencanaan Pembangunan

ABSTRACT

Villages generally have abundant natural resources so that they can become capital for economic development and tourism. Kuranji Dalang Village is one of the villages that has these advantages. Its potential includes beaches, turtle breeding and
\end{abstract}


charming mountains. Besides that, there are local products that are produced by the Kuranji Dalang community but are still having problems in marketing. Good planning is needed to manage tourism potential. Some of the counseling stages consist of, 1) Village medium-term development planning (RPJM) from theoretical aspects and 2) business development planning, namely aspects of production (goods and services), distribution, commercialization and market development aspects.

Keywords: Economic Development, Tourism, Development Planning

\section{PENDAHULUAN}

Pembangunan desa merupakan bagian intergral dari pembangunan daerah dan nasional. Hakekat pembangunan desa sebagaimana hakekat pembangunan daerah dan nasional bertujuan untuk mewujudkan masyarakat desa yang adil dan makmur, sejahtera lahir bathin. Pembangunan desa sudah lama seiring dengan lamanya pembangunan daerah dan nasional, sejak kemerdekaan sampai dengan sekarang. Sudah lamanya pembangunan desa, hasil pembangunan desa belum dapat mewujudkan kesejahteraan masyarakat sebagaimana hakekat daripada pembangunan desa. Hal ini tercermin dari tingginya tingkat kemiskinan di desa, masih banyak persoalan ekonomi dan sosial yang dihadapi oleh masyarakat.

Salah satu cara untuk meningkatkan pembangunan ekonomi desa adalah dengan melakukan pembangunan desa. Dengan adanya pembangunan desa, peningkatan ekonomi penduduk desa khususnya di desa tertinggal akan dapat dilakukan sehingga menjadi desa yang tidak tertinggal. Kondisi seperti ini memunculkan sebuah cara atau metode baru dalam hal membangun ekonomi desa yaitu melalui pemberdayaan masyarakat. Konsep pemberdayaan merupakan paradigma baru dalam pembangunan masyarakat yang melibatkan masyarakat dalam kegiatan pembangunan baik dalam perencanaan, pelaksanaan maupun evaluasi. 


\section{Jurnal ABDIMAS INDEPENDEN}

Vol. 2, No. 2, November 2021

Memberdayakan masyarakat mengandung makna

mengembangkan, memandirikan, menswadayakan dan memperkuat posisi tawar-menawar masyarakat lapisan bawah terhadap kekuatan penekan di segala bidang dan sektor kehidupan. Pemberdayaan masyarakat harus dipandang sebagai upaya untuk mempercepat dan memperluas upaya penanggulangan kemiskinan melalui koordinasi berbagai kebijakan, program dan kegiatan pembangunan, baik di tingkat pusat maupun daerah sehingga efektivitasnya memiliki signifikansi yang besar terhadap penanggulangan kemiskinan.

Pembangunan ekonomi desa tidak terlepas dari ketersediaan sumber daya pembangunan. Keterbatasan sumber daya pembangunan yang tersedia mengakibatkan pembangunan ekonomi dan sosial desa akan terbatas pula. Hal ini membawa konskuensi ketidak tercapai secara maksimal tujuan pembangunan desa yaitu kesejahteraan masyarakat yang semakin meningkat dan persoalan-persoalan yang dihadapi masyarakat semakin berkurang. Keterbatasan sumber daya modal (dana pembangunan) dan keterbatasan kualitas sumber daya manusia merupakan dua hal utama dalam pembangunan ekonomi desa. Ketersediaan potensi sumber daya alam yang melimpah tidak akan berarti banyak bagi pembangunan ekonomi desa apabila dana pembangunan ekonomi dan kualitas sumber daya manusia pelaksana pembangunan desa yang terbatas.

Keberhasilan pembangunan ekonomi desa tidak terlepas dari motivasi, pemahaman dan wawasan aparatur desa dan masyarakat desa tentang bagaimana membangun ekonomi. Tiga hal ini merupakan faktor yang penting dalam menciptakan kegiatan-kegiatan ekonomi. Motivasi menentukan sejauh mana keinginan masyarakat untuk merubah kondisi kehidupannya. Motivasi yang tinggi untuk merubah keadaan kehidupannya maka akan memungkinkan terciptanya kegiatan-kegiatan usaha ekonomi yang dilakukan. Demikian juga pemahaman aparatur desa dan masyarakat yang luas mengenai kegiatan-kegiatan usaha ekonomi maka akan tercipta 
kegiatan-kegiatan usaha eknomi dalam masyarakat. Wawasan yang luas tentang kegiatan-kegiatan usaha ekonomi yang dimiliki akan memungkinkan untuk mengadopsi kegiatan-kegiatan usaha ekonomi tersebut dalam membangun ekonomi masyarakat desa.

Pembangunan ekonomi desa harus diinisiatif dan dimotivasi serta dimotori pelaksanaanya oleh aparatur desa dan stakeholder desa. Aparatur desa dan stakeholder adalah ujung tombak dalam pembangunan desa. Karena aparatur desa dan stakeholder desa lah yang mengetahui keadaan seluruh desa baik tentang potensi desa, kegiatan ekonomi masyarakat serta sumber daya modal dan sumber daya manusia desa. Secara umum semua desa mempunyai potensi sumber daya ekonomi sama. Punya potensi sumber daya alam cukup melimpah, sumberdaya manusia yang cukup banyak, sumber daya modal yang cukup tersedia dengan adanya dana desa yang ditransfer oleh pemerintah. Potensi sumber daya alam cukup melimpah, tetapi pemanfaatannya untuk membangun ekonomi masyarakat masih belum optimal. Sumber daya manusia cukup banyak namun kualitasnya masih sangat rendah sehingga belum mampu secara maksimal memanfaatkan sumber daya alam yang tersedia. Keterbatasan pemanfaatan sumber daya alam yang tersedia dan keterbatasan kualitas sumber daya manusia menyebabkan kegiatan-kegiatan ekonomi di pedesaan kurang banyak. Akibatnya, hampir seluruh daerah pedesaan di Indonesia dalam keadaan miskin dan tingkat pengangguran tinggi.

Desa Kuranji Dalang Kecamatan Labuapi Lombok Barat Provinsi Nusa Tenggara Barat memiliki potensi sumber daya alam yang cukup tersedia, terutama potensi Pariwisata sebagai objek pembangunan. Posisi desa yang pinggir pantai dan jaraknya yang dekat dengan pusat Kota Mataram harusnya memberi landasan bagi kemajuan ekonomi desa Kuranji Dalang. Masyarakat Kota Mataram yang seharian bekerja dapat mengalokasikan waktu luangnya untuk mengunjungi objek wisata desa Kuranji Dalang. 


\section{Jurnal ABDIMAS INDEPENDEN}

Vol. 2, No. 2, November 2021

Namun, kebanyakan pemangku kepentingan di desa relatif belum memiliki kemampuan yang maksimal dalam mengidentifikasi dan merencanakan pengembangan pariwisata desa. Bardasar pertimbangan tersebut perlu dilakukan penyuluhan dalam rangka meningkatkan pengetahuan masyarakat desa dalam merencanakan program, mengidentifikasi potensi dan membangun ekonomi dan bisnis di desa.

\section{METODE KEGIATAN}

Lokasi penyuluhan dilakukan di Kantor Desa Kuranji Dalang Kecamatan Labuapi Kabupaten Lombok Barat. Penyuluhan dihadiri oleh kepala desa, beberapa kepala dusun, staf desa dan beberapa masyarakat desa. Penyuluhan dilakukan secara bergilir oleh tim pengabdian. Tahap pertama, perencanaan penyusunan Rencana Pembangunan Jangka menengah (RPJM) Desa secara konseptual dan teoritis. Kedua, penjelasan perencanaan pengembangan bisnis. Ketiga, dilakukan tanya jawab, dan keempat, penarikan kesimpulan dan langkah yang perlu dilakukan ke depan.

Gambar 1. Lokasi Penyuluhan Desa Kuranji Dalang Labuapi Lombok Barat

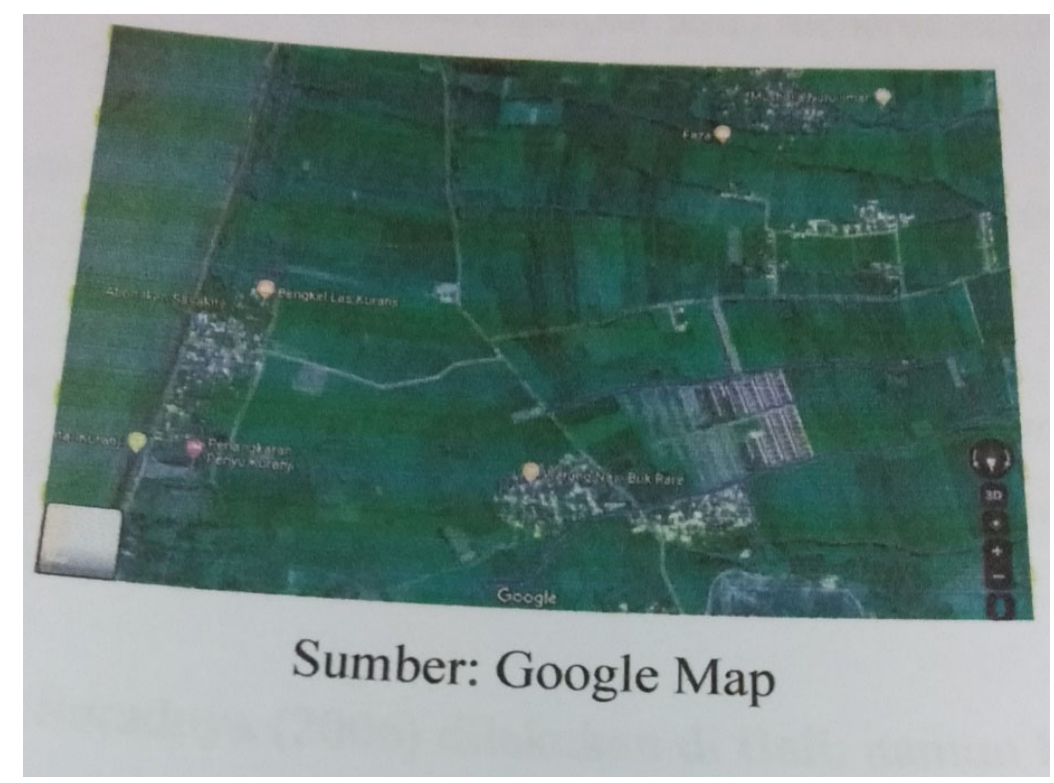




\section{PEMBAHASAN}

Beberapa persoalan yang dihadapi Desa Kuranji Dalang adalah pertama, kunjungan orang luar yang relatif minim ke desa. Kedua, infrastruktur jalan menuju desa masih relatif sempit. Ketiga, potensi wisata yang belum tergali maksimal. Keempat, persoalan persampahan yang belum optimal diselesaikan.

Dua point penting yang perlu disiapkan pemangku kepentingan di desa dalam meningkatkan perekonomian, yaitu: bagaimana mendatangkan modal (investasi) dan mendatangkan orang (pariwisata). Mendatangkan modal tentu karena ada potensi sumber daya alam desa yang potensial untuk dijadikan industri. Modal dalam konteks ini dapat berupa modal dalam negeri (PMDN) maupun modal dari luar (PMA). Namun demikian, skala desa tentu lebih kecil untuk investasi dalam arti PMA dan PMDN. Sehingga, dalam konteks industri di desa umumnya dikenal dengan industri kecil dan menengah yang mengelola SDA yang ada dengan skala kecil (modal kecil). Tugas dari pemangku kebijakan desa adalah meningkatkan skala bisnis dan industri kecil di desa. Sehingga dapat memberi nilai tambah yang luas bagi masyarakat.

Desa Kuranji Dalang bagian besar dipinggir pantai dan potensi pegunungan yang indah sangat tepat dikembangkan pariwisata. Disamping udara dan alamnya yang masih sejuk, Desa Kuranji Dalang relatif tidak terlalu jauh dari Kota Mataram sebagai pusat Kota di Provinsi Nusa Tenggara Barat. Transportasi juga relatif cukup memadai, sehingga peluang pengembangan pariwisata dapat mudah dilaksanakan. Walaupun jalan menuju desa masih relatif sempit namun beraspal. Di desa ini telah dilakukan pendampingan oleh beberapa ahli untuk dikembangkan desa wisata. Namun demikian, tetap perlu dilakukan pendampingan terus menerus untuk pariwisata yang berkelanjutan.

Hasil penelitian menunjukan, ada unsur penyebab wisatawan berkunjung (Suradnya, 2006): 


\section{Jurnal ABDIMAS INDEPENDEN}

Vol. 2, No. 2, November 2021

Harga (price), budaya (culture), pantai (beach), kenyamanan

(convenience), relaksasi (relaxation), citra (image), keindahan alam

(natural beauty), dan penduduk setempat (people).

Walaupun penelitian Suradnya (2006) dilakukan di Bali, namun beberapa faktor yang diungkap dalam penelitian tersebut relevan untuk diperhatikan daerah lain. Bahkan dalam lingkup kecil, desa. Pemangku kepentingan desa Kuranji Dalang perlu merencanakan untuk memastikan beberapa faktor tersebut dapat disediakan masyarakat Desa Kuranji Dalang.

Dari aspek bisnis, pengembangan ekonomi atau bisnis desa ada 4 tata niaga yang perlu diperhatikan, yaitu aspek produksi, distribusi, komersialisasi dan pasar (konsumsi). Aspek produksi membicarakan apa yang diproduksi, secara kualitas dan kuantitas, apakah bahan baku cukup memadai sehingga produksi berkelanjutan, apakah produk akhir memiliki daya saing sehingga dapat disukai pasar dan seterusnya. Aspek distribusi berkaitan dengan penyaluran produk dari bahan baku ke lokasi produksi, dari lokasi produksi ke pasar dan seterusnya. Aspek distribusi lebih kepada persoalan transportasi. Transportasi adalah salah satu unsur yang menyebabkan biaya membengkak dan harga menjadi mahal sehingga produk tidak memiliki daya saing.

Aspek lain adalah komersialisasi, merupakan upaya dari pelaku bisnis untuk mempromosikan dan menviralkan potensi desa. Komersialisasi ini dapat dengan media sosial dan beberapa saluran lainnya. Komersialisasi penting untuk memperkenalkan produk desa ke luar. Komersialisasi dapat dilakukan oleh pengembang perumahan ketika membuat brosur dan sejenisnya untuk memasukan latar keindahan potensi desa Kuranji Dalang. Keindahan desa Kuranji Dalang dapat dipromosikan di media-media social atau membuat video terkait penangkaran penyu di Kuranji Dalang.

Sedangkan aspek terakhir adalah aspek konsumsi atau pasar. Pasar ini merupakan muara dari aspek bisnis. Produk yan dihasilkan atau diproduksi harus mengikuti selera pasar, baik berupa produk jasa maupun 
manufaktur. Produk didistribusikan ke lokasi pasar, produk dikomersialkan untuk dikenalkan ke pasar atau dijual di pasar, baik pasar tradisional maupun pasar modern, baik secara online (platform) maupun offline. Persoalan jasa wisata kurang diminati boleh jadi pelayanan masyarakat yang tidak sesuai selera pasar (masyarakat pariwisata). Begitupun dengan persoalan produk UMKM, selama ini umumnya memproduksi apa yang bisa dan bisa dikerjakan bukan berdasarkan selera pasar, sehingga kurang mampu bersaing dengan produk luar. Produk UMKM yang tidak sesuai selera konsumen kebanyakan akhirnya menjadi produk oleh-oleh, yang laku dijual hanya ketika datang wisatawan. Sehingga produk UMKM tidak saja berorientasi oleh-oleh namun menciptakan produk yang dibutuhkan konsumen yang bukan wisatawan.

Sehingga demikian, beberapa tugas pemangku kepentingan di desa untuk mengembangkan ekonomi desa tahap awal adalah melakukan identifikasi potensi desa. Data tentang potensi desa sangat penting untuk dilakukan perencanaan dan pelaksanaan pembangunan. Biasanya dalam proses perencanaan pembangunan selalu diawali dengan data dan analisis data (Blakely dan Bradshaw, 2002:78). Data potensi desa dapat berupa potensi SDA dan SDM serta potensi modal social, sejauh mana nilai-nilai masih dipatuhi masyarakat, sejauh mana masyarakat masih saling percaya dan juga sejauh mana jaringan ekonomi yang dimiliki desa dapat digerakan untuk mengembangkan ekonomi desa.

Aspek lain yang juga penting adalah mendesain kelembagaan (institutional design). Dalam perspektif ekonomi kelembagaan (institutional economics) pengertian kelembagaan atau institusi adalah tata aturan, tata nilai, norma serta kebiasaan dalam masyarakat. Aturan terdiri dari dua jenis, yaitu aturan formal berupa undang-undang, perda, perdes yang secara formal mengatur apa yang boleh dan tidak boleh dilakukan masyarakat. Aturan non formal adalah aturan tanpa tertulis namun masyarakat anggap sebagai aturan yang menjadi kebiasaan dari generasi-ke generasi. 


\section{Jurnal ABDIMAS INDEPENDEN}

Vol. 2, No. 2, November 2021

Aturan seperti apa yang perlu disepakati desa, yaitu aturan memanfaatkan dan meningkatkan ekonomi desa, misalnya dengan menggunakan produk-produk asli desa dan lain-lain. Warga desa dianjurkan mebeli kebutuhan pokok di Bumdes yang didirikan desa adalah contoh bentuk desain kelembagaan itu. Desa Kuranji Dalang adalah desa yang kaya akan sumber daya alamnya. Sehingga Universitas Mataram menjadikan desa ini sebagai desa yang didampingi dalam program desa wisata.

Setelah penyampaian materi dilanjutkan dengan sesi tanya jawab. Beberapa perserta bertanya terkait strategi pembangunan pariwisata dan ekonomi desa dan ada juga bertanya dalam bentuk idiologis ekonomi, terkait kebijakan ekonomi negara dan haluan pemikirannya. Dalam sesi tanya jawab, salah seorang peserta bertanya apa yang perlu dilakukan untuk membangun pariwisata desa Kuranji Dalang. Tim penyuluh menjelaskan bahwa pembangunan pariwisata desa dilakukan dengan pola BPV (Bangun Poles Viralkan). Objek yang dibangun itu ada berupa objek yang paling unggul, terutama keunggulan komparatif, artinya daerah lain tidak memiliki objek semacam itu. Setelah dibangun kemudian dibuat kelembagaan, berupa tata aturan tertulis dana tidak tertulis serta organisasi yang mengelola kawasan wisata tersebut. Pembentukan kelembagaan penting untuk menentukan job deskripsi pengelolaan. Siapa yang menjadi penanggung jawab, ketua, sekretaris sampai dengan keamanan. Disamping itu dibuat tata aturan bagaimana masyarakat lokal berprilaku menyambut tamu dan tata aturan lainnya.

Setelah objek telah dibangun dan dipoles serta telah terbentuk kelembagaannya baru kemudian diviralkan. Menviralkan lokasi wisata dapat dilakukan dengan media-media social atau ikut dipaparkan dalam iklan perumahan di desa yang dibangun oleh pengembang. Pola ini menguntungkan pengembang juga, karena lokasi perumahan yang dibangun terdapat objek wisata yang indah. 


\section{KESIMPULAN DAN SARAN}

Dalam rangkaian kegiatan penyuluhan yang dilakukan, ada beberapa kesimpulannya dalam membangun ekonomi dan pariwisata desa Kuranji Dalang. 1) Identifikasi potensi, 2) bangun dan poles lokasi tersebut secara baik dengan prinsip pengembangan tata niaga, produksi, distribusi, komersialisasi dan pasar. 3) Buat kelembagaan atau tata aturannya, 4) Viralkan lokasi wisata tersebut dengan berbagai jalan.

\section{UCAPAN TERIMA KASIH}

Terlaksananya kegiatan Pengabdian Kepada Masyarakat ini, tidak terlepas dari peran berbagai pihak. Oleh karena itu pada kesempatan ini kami (Tim pengabdian) mengucapkan terima Kasih dan penghargaan kepada:

1. Ketua LPPM Unram yang telah menyediakan dana pengabdian yang bersumber dari PNBP

2. Kepala Desa Kuranji Dalang dan Sekertaris beserta staff yang telah mendukung kegiatan pengabdian dengan menyiapkan ruangan (AULA kantor desa) dan fasilitas pendukung lain yang diperlukan.

3. Tim Penggerak PKK Desa di Desa Kuranji Dalang yang telah bersedia untuk memotivasi dan mengikuti kegiatan pelatihan.

\section{DAFTAR PUSTAKA}

Bradshaw K dan Blakely, EJ. 2002. Planning Local Economic Development: Theory and Practice. Sage Publications

Jamal, T.B dan Gezt, D, 1995. Collaboration Theory and Community Tourism Planning. Annals of Tourism Research. Volume 22, Issue 1, 1995, Pages 186-204.

Suradnya, IM, 2006. Analisis Faktor-faktor Daya Tarik Wisata Bali Dan Implikasinya Trehadap Perencanaan Pariwisata Daerah Bali. SOCA (Jurnal Sosial Ekonomi Pertanian, Vol. 6 No.3 Nomvember. 